\title{
Commentary
}

\section{Risk Compensation: Revisited and Rebutted}

\author{
Barry Pless
}

Professor Emeritus, Pediatrics and Epidemiology, McGill University, 434 Lansdowne, Westmount, QC H3Y2V2, Canada; barry.pless@mcgill.ca; Tel.: +1-514-935-9264

Academic Editor: Jake Olivier

Received: 3 March 2016; Accepted: 22 August 2016; Published: 29 August 2016

\begin{abstract}
This Commentary addresses the ongoing disagreements between many safety advocates who endorse traditional models of prevention and those who oppose them, arguing that safety measures are offset by risk compensation (RCT). The debate is especially heated with respect to regulatory or legislative prevention measures. After explaining the rationale behind risk compensation (aka risk homeostasis theory) (RHT), I provide examples of RCT studies to explain why I believe they should be rejected. The main basis for my rebuttal, however, rests on data that show steady declines in unintentional injury mortality, which, according to RCT, should not have occurred. There are many other reasons for rejecting this theory, and it seems that the time has come for the debate to finally be concluded.
\end{abstract}

Keywords: risk compensation; risk homeostasis

\section{Introduction}

This paper is a distillation, update, and rebuttal of Risk Compensation Theory (RCT). It arises from a debate I engaged in with Gerald Wilde, the most prominent popularizer of the Risk Compensation idea. That debate took place over 20 years ago at a meeting of health journalists in Montreal.

In this Commentary, I will restate Wilde's theory as best I can and then provide a rebuttal. I begin with three important reminders:first, RCT initially was-and remains-a hypothesis or theory. It is still unproven. Second, for some the issue entails whether efforts to prevent injuries can ever be successful if RCT were genuine. Third, although I frequently reference Wilde's original arguments, it is in fact his often less thoughtful but equally zealous followers who continue to use RCT as a reason for rejecting safety measures.

As this is a Commentary, I make no pretense at providing a comprehensive or systematic review of the recent literature on this topic as it pertains to injuries. I did, however, want to be certain that I had not overlooked any important new papers on either side of the debate. To that end, using Google Scholar and Medline Ovid, I conducted a search for papers published since 2012 with the terms "risk homeostasis" or "risk compensation" in the title or abstract. I then combined that search with "wounds or injuries". Most of the results are included in this commentary or in the Supplement.

\section{Background}

I trust readers do not need to be reminded of the importance of injuries and their prevention. The recent Global Burden of Disease and Injury report estimates that in 2013 about 4.8 million people worldwide died from injuries [1,2]. As shown in Figure 1 below, in the US injuries have been, and remain, the leading cause of death among those aged 1-45 years [3]. In addition, they are a major cause of hospitalization and often result in serious permanent disability. Hence, injuries are an important but often neglected, public health problem. 
10 Leading Causes of Death by Age Group, United States - 2013

\begin{tabular}{|c|c|c|c|c|c|c|c|c|c|c|c|}
\hline & \multicolumn{10}{|c|}{ Age Groups } & \multirow[b]{2}{*}{ Total } \\
\hline Rank & $<1$ & 1.4 & $5-9$ & $10-14$ & $15-24$ & $25-34$ & 35.44 & $45-54$ & $55-64$ & $65+$ & \\
\hline 1 & $\begin{array}{c}\text { Congenital } \\
\text { Anomalies } \\
4,758\end{array}$ & $\begin{array}{c}\text { Unintentional } \\
\text { Injury } \\
\mathbf{1 , 3 1 6}\end{array}$ & $\begin{array}{l}\text { Unintentional } \\
\text { Injury } \\
746\end{array}$ & $\begin{array}{l}\text { Unintentional } \\
\text { Injury } \\
775\end{array}$ & $\begin{array}{l}\text { Unintentional } \\
\text { Injury } \\
\mathbf{1 1 , 6 1 9}\end{array}$ & $\begin{array}{c}\text { Unintentional } \\
\text { Injury } \\
\mathbf{1 6 , 2 0 9}\end{array}$ & $\begin{array}{c}\text { Unintentional } \\
\text { Injury } \\
15,354\end{array}$ & $\begin{array}{c}\text { Malignant } \\
\text { Neoplasms } \\
46,185\end{array}$ & $\begin{array}{c}\text { Malignant } \\
\text { Neoplasms } \\
113,324\end{array}$ & $\begin{array}{c}\text { Heart } \\
\text { Disease } \\
488,156\end{array}$ & $\begin{array}{c}\text { Heart } \\
\text { Disease } \\
611,105\end{array}$ \\
\hline 2 & $\begin{array}{c}\text { Short } \\
\text { Gestation } \\
4,202\end{array}$ & $\begin{array}{c}\text { Congenital } \\
\text { Anomalies } \\
476\end{array}$ & $\begin{array}{l}\text { Malignant } \\
\text { Neoplasms } \\
\quad 447\end{array}$ & $\begin{array}{l}\text { Malignant } \\
\text { Neoplasms } \\
448\end{array}$ & $\begin{array}{l}\text { Suicide } \\
4,878\end{array}$ & $\begin{array}{l}\text { Suicide } \\
6,348\end{array}$ & $\begin{array}{c}\text { Malignant } \\
\text { Neoplasms } \\
11,349\end{array}$ & $\begin{array}{c}\text { Heart } \\
\text { Disease } \\
35,167\end{array}$ & $\begin{array}{c}\text { Heart } \\
\text { Disease } \\
72,568\end{array}$ & $\begin{array}{c}\text { Malignant } \\
\text { Neoplasms } \\
407,558\end{array}$ & $\begin{array}{c}\text { Malignant } \\
\text { Neoplasms } \\
584,881\end{array}$ \\
\hline 3 & $\begin{array}{c}\text { Maternal } \\
\text { Pregnanoy } \\
\text { Comp. } \\
1,595 \\
\end{array}$ & $\begin{array}{l}\text { Homicide } \\
337\end{array}$ & $\begin{array}{c}\text { Congenital } \\
\text { Anomalies } \\
179\end{array}$ & $\begin{array}{c}\text { Suicide } \\
386\end{array}$ & $\begin{array}{l}\text { Homicide } \\
4,329\end{array}$ & $\begin{array}{l}\text { Homicide } \\
4,236\end{array}$ & $\begin{array}{c}\text { Heart } \\
\text { Disease } \\
10,341\end{array}$ & $\begin{array}{l}\text { Unintentional } \\
\text { Injury } \\
20,357\end{array}$ & $\begin{array}{c}\text { Unintentional } \\
\text { Injury } \\
17,057\end{array}$ & $\begin{array}{c}\text { Chronic Low. } \\
\text { Respiratory } \\
\text { Disease } \\
127,194 \\
\end{array}$ & $\begin{array}{c}\text { Chronic Low. } \\
\text { Respiratory } \\
\text { Disease } \\
149,205\end{array}$ \\
\hline 4 & $\begin{array}{l}\text { SIDS } \\
1,563\end{array}$ & $\begin{array}{l}\text { Malignant } \\
\text { Neoplasms } \\
328\end{array}$ & $\begin{array}{l}\text { Homicide } \\
125\end{array}$ & $\begin{array}{c}\text { Congenital } \\
\text { Anomalies } \\
161\end{array}$ & $\begin{array}{c}\text { Malignant } \\
\text { Neoplasms } \\
1,496\end{array}$ & $\begin{array}{l}\text { Malignant } \\
\text { Neoplasms } \\
3,673\end{array}$ & $\begin{array}{l}\text { Suicide } \\
6,551\end{array}$ & $\begin{array}{l}\text { Liver } \\
\text { Disease } \\
8,785\end{array}$ & $\begin{array}{c}\text { Chronic Low. } \\
\text { Respiratory } \\
\text { Disease } \\
15,942 \\
\end{array}$ & $\begin{array}{l}\text { Cerebro- } \\
\text { vascular } \\
109,602\end{array}$ & $\begin{array}{c}\text { Unintentional } \\
\text { Injury } \\
130,557\end{array}$ \\
\hline 5 & $\begin{array}{c}\text { Unintentional } \\
\text { Injury } \\
\mathbf{1 , 1 5 6}\end{array}$ & $\begin{array}{c}\text { Heart } \\
\text { Disease } \\
169\end{array}$ & $\begin{array}{l}\text { Chronic Low. } \\
\text { Respiratory } \\
\text { Disease } \\
75 \\
\end{array}$ & $\begin{array}{l}\text { Homicide } \\
152\end{array}$ & $\begin{array}{c}\text { Heart } \\
\text { Disease } \\
941\end{array}$ & $\begin{array}{c}\text { Heart } \\
\text { Disease } \\
3,258\end{array}$ & $\begin{array}{c}\text { Homicide } \\
2,581\end{array}$ & $\begin{array}{l}\text { Suicide } \\
8,621\end{array}$ & $\begin{array}{c}\text { Diabetes } \\
\text { Mellitus } \\
13,061\end{array}$ & $\begin{array}{c}\text { Alzheimer's } \\
\text { Disease } \\
83,786\end{array}$ & $\begin{array}{l}\text { Cerebro- } \\
\text { vascular } \\
128,978\end{array}$ \\
\hline 6 & $\begin{array}{c}\text { Placenta } \\
\text { Cord. } \\
\text { Membranes } \\
953\end{array}$ & $\begin{array}{c}\text { Influenza \& } \\
\text { Pneumonia } \\
\quad 102\end{array}$ & $\begin{array}{c}\text { Heart } \\
\text { Disease } \\
73 \\
\end{array}$ & $\begin{array}{c}\text { Heart } \\
\text { Disease } \\
100\end{array}$ & $\begin{array}{c}\text { Congenital } \\
\text { Anomalies } \\
362\end{array}$ & $\begin{array}{c}\text { Diabetes } \\
\text { Mellitus } \\
684\end{array}$ & $\begin{array}{c}\text { Liver } \\
\text { Disease } \\
2,491 \\
\end{array}$ & $\begin{array}{c}\text { Diabetes } \\
\text { Mellitus } \\
5,899\end{array}$ & $\begin{array}{c}\text { Liver } \\
\text { Disease } \\
11,951 \\
\end{array}$ & $\begin{array}{c}\text { Diabetes } \\
\text { Mellitus } \\
53,751\end{array}$ & $\begin{array}{c}\text { Alzheimer's } \\
\text { Disease } \\
84,767\end{array}$ \\
\hline 7 & $\begin{array}{c}\text { Bacterial } \\
\text { Sepsis } \\
578\end{array}$ & $\begin{array}{c}\text { Chronic Low. } \\
\text { Respiratory } \\
\text { Disease } \\
64\end{array}$ & $\begin{array}{c}\text { Influenza \& } \\
\text { Pneumonia } \\
67\end{array}$ & $\begin{array}{c}\text { Chronio Low } \\
\text { Respiratory } \\
\text { Disease } \\
80\end{array}$ & $\begin{array}{c}\text { Influenza \& } \\
\text { Pneumonia } \\
197\end{array}$ & $\begin{array}{c}\text { Liver } \\
\text { Disease } \\
676\end{array}$ & $\begin{array}{c}\text { Diabetes } \\
\text { Mellitus } \\
1,952\end{array}$ & $\begin{array}{l}\text { Cerebro. } \\
\text { vascular } \\
5,425\end{array}$ & $\begin{array}{l}\text { Cerebro- } \\
\text { vascular } \\
11,364\end{array}$ & $\begin{array}{c}\text { Influenza \& } \\
\text { Pneumonia } \\
48,031\end{array}$ & $\begin{array}{l}\text { Diabetes } \\
\text { Mellitus } \\
75,578 \\
\end{array}$ \\
\hline 8 & $\begin{array}{l}\text { Respiratory } \\
\text { Distress } \\
522\end{array}$ & $\begin{array}{c}\text { Septicemia } \\
53\end{array}$ & $\begin{array}{c}\text { Cerebro- } \\
\text { vascular } \\
41\end{array}$ & $\begin{array}{c}\text { Influenza \& } \\
\text { Pneumonia } \\
\quad 61\end{array}$ & $\begin{array}{c}\text { Diabetes } \\
\text { Mellitus } \\
193\end{array}$ & $\begin{array}{l}\text { HIV } \\
631\end{array}$ & $\begin{array}{c}\text { Cerebro- } \\
\text { vascular } \\
1,687\end{array}$ & $\begin{array}{l}\text { Chronic Low. } \\
\text { Respiratory } \\
\text { Disease } \\
4,619\end{array}$ & $\begin{array}{c}\text { Suicide } \\
7,135\end{array}$ & $\begin{array}{c}\text { Unintentional } \\
\text { Injury } \\
\mathbf{4 5 , 9 4 2}\end{array}$ & $\begin{array}{c}\text { Influenza \& } \\
\text { Pneumonia } \\
56,979\end{array}$ \\
\hline 9 & $\begin{array}{l}\text { Circulatory } \\
\text { System } \\
\text { Disease } \\
458 \\
\end{array}$ & $\begin{array}{c}\text { Benign } \\
\text { Neoplasms } \\
47\end{array}$ & $\begin{array}{c}\text { Septicemia } \\
35\end{array}$ & $\begin{array}{c}\text { Cerebro- } \\
\text { Vascular } \\
48 \\
\end{array}$ & $\begin{array}{c}\text { Complicated } \\
\text { Pregnancy } \\
178 \\
\end{array}$ & $\begin{array}{c}\text { Cerebro- } \\
\text { vascular } \\
508\end{array}$ & $\begin{array}{c}\text { HIV } \\
1,246\end{array}$ & $\begin{array}{l}\text { Septicemia } \\
2,445\end{array}$ & $\begin{array}{c}\text { Septicemia } \\
5,345\end{array}$ & $\begin{array}{l}\text { Nephritis } \\
39,080\end{array}$ & $\begin{array}{l}\text { Nephritis } \\
47,112\end{array}$ \\
\hline 10 & $\begin{array}{c}\text { Neonatal } \\
\text { Hemonhage } \\
389\end{array}$ & $\begin{array}{c}\text { Perinatal } \\
\text { Period } \\
45\end{array}$ & $\begin{array}{c}\text { Benign } \\
\text { Neoplasms } \\
34\end{array}$ & $\begin{array}{c}\text { Benign } \\
\text { Neoplasms } \\
31\end{array}$ & $\begin{array}{l}\text { Chronic Low. } \\
\text { Respiratory } \\
\text { Disease } \\
155\end{array}$ & $\begin{array}{c}\text { Influenza \& } \\
\text { Pneumonia } \\
\quad 449\end{array}$ & $\begin{array}{l}\text { Influenza \& } \\
\text { Pneumonia } \\
\quad 881\end{array}$ & $\begin{array}{c}\mathrm{HIV} \\
2,378\end{array}$ & $\begin{array}{c}\text { Nephritis } \\
4,947\end{array}$ & $\begin{array}{l}\text { Septicemia } \\
28,815\end{array}$ & $\begin{array}{l}\text { Suicide } \\
41,149\end{array}$ \\
\hline
\end{tabular}

Figure 1. Leading causes of death by age [3].

Although often credited to Gerald Wilde, a professor at Queens University in Canada, RCT appears to have originated with Peltzman, a University of Chicago professor of economics [4]. In a paper published in 1975 regarding traffic deaths Peltzman suggested that "offsets (due to risk compensation) are virtually complete, so that regulation has not decreased highway deaths". Broadly, the so-called Peltzman effect argues that there will be "no reduction of predicted benefit from regulations that intend to increase safety." Accordingly, he asserts, regulation is, "at best, useless, and at worst, counterproductive." (Note that a reanalysis of Peltzmans original data by Robertson in 1977 found numerous errors) [5] and, as will be seen, many later studies, found strong evidence that regulations do prevent injuries. For example, in the U.S., motor vehicle fatalities fell by more than half from the beginning of regulations such as lap belts introduced in the 1960s through 2012 [6].

In 1982 Wilde resurrected the Peltzman idea. At times he called it "risk homeostasis theory" (RHT) and at others, "risk compensation theory" (RCT) [7]. The distinction is not clear and for clarity I will use RCT to represent both ideas unless citing work that emphasizes the term RHT. Both theories propose that we each have a target level of risk that is influenced by how we estimate the costs and benefits of risky or safe behavior and that we adjust our behavior to maintain that level. This is the central message of Wilde"s later book, Target Risk, published in 1994 [8]. (There have been two further editions, the latest available free online). It is important to emphasize the confusion between the terms risk compensation and risk homeostasis. It is not just Peltzman that interchanges them but Wilde himself appears to have shifting preferences. Thus it is not surprising that some readers consider the terms to be synonymous while others believe they represent sharply different ideas. This is compounded by the notion, added by others (not Wilde), of 'complete' vs. 'partial' risk compensation. I cannot address this idea because it was not mentioned in the original debate nor do these distinctions emerge in reviews of most research on the topic. More importantly, perhaps, I fail to understand the distinction in the context of this debate. 
To be certain I am not doing Wilde an injustice, this is his explanation verbatim: "The level of risk at which the net benefit is expected to maximize is called the target level of risk in recognition of the realization that people do not try to minimize risk (which would be zero at zero mobility), but instead attempt to optimize it. Risk homeostasis theory posits that people at any moment of time compare the amount of risk they perceive with their target level of risk and will adjust their behaviour in an attempt to eliminate any discrepancies between the two. Each action carries a certain level of injury likelihood such that the sum total of all actions taken by people over one year explains the accident rate for that year. This rate, in turn, has an effect on the level of risk that people perceive and thus upon their subsequent decisions, and so forth." [9].

\section{RCT Revisited: Examples for and against the Theory}

An early topic chosen to support the RC theory was traffic accidents in general and seat belt use in particular. It was argued that any traffic safety measure was entirely offset by increased speeding or more careless driving (as Peltzman asserted it would). However, as Evans writes, "to examine the validity of this claim, using a wide variety of traffic accident data, all the data examined are found to be incompatible with the risk homeostasis theory ... The accident data provide evidence that a rich variety of user responses occur. While it is possible for users to collectively respond in such a way that safety benefits are completely cancelled, such a response is not particularly common; it is certainly not universally occurring, as suggested by the risk homeostasis theory. It is concluded that the risk homeostasis theory should be rejected because there is no convincing evidence supporting it and much evidence refuting it." [10].

A related example-the alleged ineffectiveness of airbags—is rejected by $\mathrm{O}^{\prime} \mathrm{Neill}$ and Williams. "Wilde cites an article claiming to show that airbag equipped cars tend to be driven more aggressively and that aggressiveness appears to offset the effect of the airbag for the driver. (However), he chooses not to cite the many studies that show significant reductions in driver deaths in airbag equipped cars ..." "[11].

When Sweden changed from driving on the left to driving on the right in 1967 this was first followed by a marked reduction in road death rates. However, Wilde notes, this only lasted for 18 months. Subsequently, the trend returned to its previous levels. He takes this as evidence that initially drivers had responded to greater perceived dangers by taking more care, but once they became accustomed to driving on the right they reverted to their previous (presumably careless) driving behavior. What he neglects to add is the conclusion reported in a Monograph examining the left-right change: "Accident experience in the first two months show that fatal accidents are much below the average rate, and total accidents have occurred at a rate about average." [12].

A study in Munich is also often quoted to support RCT. One part of a fleet of taxicabs was equipped with anti-lock braking systems (ABS) while the rest had conventional brakes. Crash rates over the next three years were examined and found either to be a little higher for the cabs with ABS or substantially the same for both types of taxi, depending on which account you read. Wilde chose the former and concluded the results were due to drivers of ABS-equipped cabs taking more risks, assuming that ABS would take care of them, whereas the non-ABS drivers drove more carefully [13]. However, this conclusion needs to be considered against a report by the Insurance Institute for Highway Safety that found that motorcycles with ABS were 37\% less likely to be involved in a fatal crash than models without ABS [14]. Wikipedia explains, "On high-traction surfaces such as bitumen, or concrete, many (though not all) ABS-equipped cars are able to attain braking distances better (i.e., shorter) than those that would be possible without the benefit of ABS." [15].

Another controversial example is Graduated Driver Licensing (GDL). Wilde dismisses this initiative as a failure but neglects to acknowledge that most GDL programs resulted in many more teenage drivers, offsetting any benefits of GDL. He states that North American data show about the same per capita MV death rate in 1996 as in 1923 but there was actually a 60\% decline between 1964 and 1990 [16]. A recent review by Peck concludes: “The results of Canadian studies indicate that any 
effects of the driver training component are not sufficient to offset the increase in accidents due to increased exposure." [17,18].

Finally, as noted elsewhere, RCT is often supported by a bewildering rationale-so-called 'system effects'. For example, crackdowns on speeding or driving while intoxicated are claimed to be useless because they simply shift deaths to other causes. Along the same lines, it is argued that any decrease in car occupant deaths, e.g., due to seat belt use, could be offset by an increase in pedestrian deaths. However, further analyses of same data show that not only did cars complying with belt regulations have $40 \%$ fewer occupant deaths, they were also much less likely to strike others than non-regulated cars [19].

\section{Child-Related Examples}

Much of the controversy surrounding RCT uses examples from the literature on child injuries. Studies by Morrongiello, a child psychologist, assert that the phenomenon truly exists [20-22]. Another supporter is Dillilo who reported that mothers who viewed "stimulus materials depicting the use of safety precautions" showed significantly higher levels of tolerance for risky behavior on the part of their children than did mothers who viewed identical materials without the safety precautions. From this Dillilo concluded that there may be a compensatory mechanism at work [23]. One important limitation of the studies by both researchers is that most are laboratory based and thus inconclusive with respect to their real-life implications. In contrast, another study based on actual interviews following an injury, provides no support for RCT [24].

The percent change in 6 specific causes of injury fatalities for those younger than 20 years in Canada between 1962 and 1996 reveals a decline that is roughly the same across all types of injury, including poisonings. Interestingly, however, Wilde uses poison packaging as another example to support RCT, concluding that child poisoning has not benefited from this measure because of RCT. He states that "The introduction of childproof medicine vials has failed to limit the number of cases of accidental poisoning. These, in fact, became more frequent, apparently as the result of parents becoming less careful in the handling and storing of the "safer" bottles." However, the data show that in Canada, and presumably elsewhere, the fall in poisoning fatalities among the young was $47 \%$ over the 35-year period following 1962 when packaging became widespread. One early study showed that since passage of an Act in the US requiring child resistant packaging, more than 700 children's lives have been saved from poisonings by prescription drugs and aspirin alone [25]. Many other studies have reached the same conclusion [26-28].

Similarly, Wilde asserts that cigarette lighter safety regulations have failed even though one study author concluded, "On balance, the child-proof feature will reduce burns much more than any diminished precautions." [29].

\section{The Never-Ending Helmet Controversy}

Although many new papers citing RCT relate to sexual behavior, the undoubted winner for ongoing controversy is helmet use. Opponents take positions ranging from claiming helmets are completely ineffective to suggesting they are actually harmful, often using RCT to support their views.

\section{Bicycle and Motorcycle Helmets}

A well publicized paper by Gamble and Walker appeared in a psychology journal [30]. It described a lab experiment based on the assumption that RCT has been proven. 80 adults were assigned to wear either a baseball cap or a bicycle helmet. Wearers were seated at computers with cameras on their headwear. They then played a game that involved pushing buttons to inflate an on-screen balloon without popping it and in doing so were encouraged "to take risks". Apparently those who wore helmets inflated the balloons with more air than those who wore the caps. Thus, it is reasoned, they took more risks! This prompted an anti-helmet critic to suggest "a rethink of bike helmet laws is needed" and "the government must stop its war on cyclists" [31]. However, the article's authors add, 
"If this laboratory demonstration of globally increased risk taking arising from localized protection were to be replicated in real settings, this could suggest that people using protective equipment against specific hazards might also be unduly inclined to take risks that such protective equipment cannot reasonably be expected to guard against."

Another such study reached the opposite conclusion but failed to capture the same media attention. In spite of an impressive sample of motorcycle helmet laws, the study designed to "test the hypotheses of offsetting and enhancing behavior with regards to motorcycle helmet legislation" ... found "no evidence of offsetting behavior and are consistent with the presence of enhancing behavior. State motorcycle helmet laws are estimated to reduce motorcycle crashes by $18.4 \%$ to $31.9 \%$." [32].

A simulation model using a six-year-old child dummy provided a "direct evaluation of helmet efficacy by using computational modelling to simulate a range of realistic accident scenarios, including loss of control, collision with static objects and vehicle impact." One conclusion, other than showing the efficacy of the helmet, was that cycling speeds did not increase as would be expected if risk compensation had occurred [33].

Somewhat perplexing is a report by Fyhri et al. from Norway that tests if previous helmet use influences the response to helmets as a safety intervention. The study involved "a field experiment where pace and psychophysiological load were measured." It found that after having removed their helmets, routine helmet users cycled more slowly and demonstrated increased psychophysiological load. However, for non-users there was no significant change in either cycling behaviour or psychophysiological load [34]. Perhaps even more puzzling is one of the few randomized trials of helmet use in relation to RCT. A study in France by Messiah and colleagues measured changes in speed following helmet use adoption. They made 621 video recordings of 587 participants. There were no differences among the women whereas male cyclists who were helmeted went $2.4 \mathrm{~km} / \mathrm{h}$ faster. The conclusion "Risk compensation, observed only among male cyclists, was moderate, thus unlikely to offset helmet preventive efficacy." [35].

\section{Ski and Snowboard Helmets}

Many other studies find some support for RCT but often use questionable methods. One is a report by Thomson and Carlson on risk taking among skiers wearing helmets. Unfortunately, instead of observing behaviours the authors measured risk taking using a 'validated 10-item self-report measure'. They conclude, "The relationship between helmet use and risk taking was modest suggesting that the costs of increased risk taking is not likely to outweigh the protective benefits of a helmet." [36]. More convincing is a much larger study $(n=2000)$ from Austria that also used a similar self-report approach. The main finding is that "risk-taking behavior and ski helmet use seem not to be associated with accident causes leading to an injury among recreational skiers and snowboarders." [37-39].

Another example is a Canadian study involving self reports of 1779 adult skiers and snowboarders. It found that helmet wearers reported that they skied/snowboarded at slower speeds and challenged themselves less than non- helmet wearers. The conclusion was simply that "No evidence of risk compensation among helmet wearers was found", adding, "decisions to wear helmets may be part of a risk reduction orientation." [40].

An even larger study by Hagel and colleagues concluded, "There was no evidence that helmet use increased the risk of severe injury or high-energy crash circumstances. The results suggest that helmet use in skiing and snowboarding is not associated with riskier activities that lead to non-head-neck injuries." [41].

Along similar lines, Russell, Christie, and Hagel, concluded from a meta-analysis, "Our work suggests no relation between helmet use and severity of injury or crash circumstances (non-helmet equipment damage, fast self-reported speed, participation in more difficult runs than normal, or jumping-related injury) after adjustment for confounding variables. The available evidence suggests that, if helmet users exhibit compensating behaviour, their level of injury risk is not higher than that of nonusers." [42]. Haider et al. did an extensive systematic review of the literature on 
the efficacy of safety helmets during skiing or snowboarding. They used several databases from 1980 to 2011. Sixteen published studies met the inclusion criteria. The conclusion was a Level II recommendation/observation "that helmets do not seem to increase risk compensation behavior, neck injuries, or cervical spine injuries among skiers and snowboarders." [43].

A letter to the editor of Epidemiology from Ruedl and colleagues (2012) completes this part of the picture. The title is "Does Risk Compensation Undo the Protection of Ski Helmet Use?" The letter includes a detailed summary of previous risk-compensation work in this area and concludes, " ... . available data do not support the risk compensation theory in this special field, and the risky behavior in some ski helmet wearers is no argument against the protective effect of ski helmet use." [44].

\section{Summary of Rebuttal}

RCT is often used as a smokescreen by some who are opposed to tough safety measures such as helmet legislation and even voluntary helmet use. Policy makers may also use it as a crutch to avoid hard decisions. If taken as proven, it could seriously inhibit prevention research because, logically, if all safety measures are offset, why bother?

However, this is how science works, or is supposed to work: we identify a problem, formulate a theory or hypothesis as part of the solution, and then test the hypothesis as best we can. The 'best' means using the most powerful designs and measures available. We then publish all the evidence from our studies and respond openly and fully to any criticisms. If we are forced to accept that our theory is wrong or has been disproven, we go back to the drawing board and reformulate it.

In contrast, to the best of my knowledge, few have tried to test RCT theory empirically. By empirically I mean using a randomized trial design rather than methods that are essentially observational. Nor has anyone who is convinced of the truth of RCT offered any plausible interventions to promote safety other than somehow persuading people to reset their risk taking (thermostat) at a lower level. But how this can be done is never explained.

Those convinced that RCT has been proven rarely cite work that fails to support the RHT. We don't often find discussions of the corollary: That fewer safety measures should result in less risk taking. It is also noteworthy that so much emphasis is placed on examples from car crashes and far less on data from other injuries where the theory should work in the same way. Finally, and most damningly, the steady decline in injury death rates is either dismissed or left unexplained.

RCT flies directly in the face of the assertion that most injuries are preventable. We need to understand how it is possible for this to be true while the evidence clearly shows a marked decline in injury deaths in most of the world over the last 50 years. Although many other factors are undoubtedly at play, credit is most likely due to the same safety measures RCT believers are inclined to dismiss. How is this decline possible in light of RCT assumptions unless the entire population has lowered its tolerable risk target? Or, if miraculously this happened, what brought it about?

Figure 2 shows the decline in unintentional injury death rates for Americans of all ages from 1961 to the year 2000. For Canadian children and adolescents the unintentional injury death rate in each decade from 1920 to 1980 hovered around 40 per 100,000. Subsequently the rate fell to between 15 and 20 per 100,000 - a 64\% decline for injury deaths of all causes except homicide and suicide where few new preventive measures had been introduced. Over a longer period, from 1950 to 2009, the rate decrease was $86 \%$.

When the data fail to support the RCT theory the studies are often dismissed as dealing only with small subsets of the population or that they rely too heavily on conventional tests of statistical significance. Or, it is argued that these studies "ignore system effects". What does this mean? One bizarre example is that even if helmet laws may have reduced motorcycle deaths, it is possible that those protected will turn to sky diving as a substitute form of risk taking to maintain their homeostatic target.

If RCT were true, it should work in both directions. In situations where there is no safety measure in place, but an actual or perceived risk persists, the population would have to behave 
more cautiously to maintain homeostasis. It seems far more plausible to view safety behaviours as synergistic, i.e., that they reinforce one another. When we decide to use one safety measure this increases the likelihood that we will use other such measures including less risk taking. The user is being sensitized to being more cautious.

\section{US unintentional injury mortality all ages, both sexes}

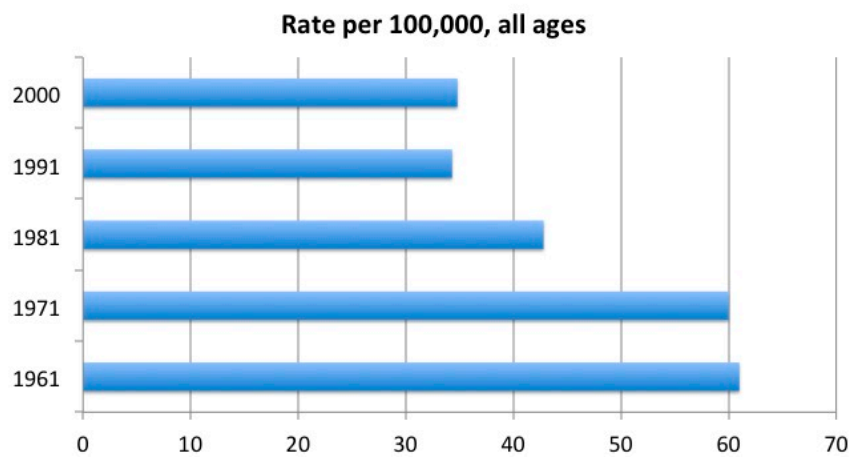

Figure 2. Death rates (per 100,000) unintentional injuries, US, 1961-2000, all ages, both sexes.

Wilde's solution to improving safety is a system of rewards or incentives. "The remarkable effectiveness of incentive programmes is arguably due to the fact that they enhance people's perceived value of the future. The prospect of future gratification causes people to look forward to the future with positive expectation. They will thus have a greater desire to be alive and well when that future comes ... and be more inclined to take action to protect their health and safety." [45]. What I think this means is that the solution lies in wanting to live longer.

In a scathing conclusion to a published rebuttal, $\mathrm{O}^{\prime}$ Neill and Williams write, "It is not surprising that many other researchers who have studied this issue have concluded that risk homeostasis has no credence as a theory and is almost entirely lacking in empirical support." [11]. Similarly, Haight noted, "In my view, a sufficient argument against the validity of risk homeostasis is provided by the incoherence of its 'theoretical' formulation" [46]. Evans, likewise, concluded that "there is no convincing evidence supporting it and much evidence refuting it" [10]. In 1991, Evans further noted that "the tone of advocacy for the claim has been largely philosophical, metaphysical, and theological in nature, unencumbered by the standards, methods, or norms of science, and at times happily abandoning the rigors of Aristotelian logic and the multiplication table." [47].

\section{Conclusions (The Final Irony)}

'RCT', the acronym for Risk Compensation Theory, is also commonly used for 'Randomized Controlled Trial'. It is curious that there have been no such real-life trials. One explanation may be that there are no feasible interventions that flow from RCT (except, perhaps, psychotherapy). In light of this it is important to ask what advice might Wilde offer to enhance safety? As noted above, his reply appears to be that the main route to changing the risk thermostat is "to give people reason for wanting to live longer". I do not suppose many truly need such a reason to be provided so perhaps that suggestion can be overlooked. Finally, in a key report by Rivara and colleagues, using a Delphi technique to determine the important research questions for the injury prevention field, risk compensation received only 1 vote from a total of 79 questions [48]. Thus, perhaps the bottom line of this Commentary is 'enough said'; this is a dead horse that no longer needs to be beaten.

Supplementary Materials: The supplementary materials are available online at www.mdpi.com/2313-576X/2/3/ $16 /$ s1. I have provided additional references to work done on this topic but not cited in the text. 
Author Contributions: I am solely responsible for the content of this paper.

Conflicts of Interest: The author declare no conflict of interest.

\section{References}

1. Global Burden of Disease Study 2013 Collaborators. Global, regional, and national incidence, prevalence, and years lived with disability for 301 acute and chronic diseases and injuries in 188 countries, 1990-2013: A systematic analysis for the Global Burden of Disease Study 2013. Lancet 2015, 386, 743-800.

2. Haagsma, J.A.; Graetz, N.; Bolliger, I.; Naghavi, M.; Higashi, H.; Mullany, E.C.; Abera, S.F.; Abraham, J.P.; Adofo, K.; Alsharif, U.; et al. The global burden of injury: Incidence, mortality, disability-adjusted life years and time trends from the Global Burden of Disease study 2013. Inj. Prev. 2016, 22, 3-18. [CrossRef] [PubMed]

3. Ten Leading Causes of Death and Injury. Available online: http://www.cdc.gov/injury/wisqars (accessed on 29 February 2016).

4. Peltzman, S. The effect of automobile safety regulation. J. Political Econ. 1975, 83, 677-726. [CrossRef]

5. Robertson, L.S. A critical analysis of Peltzman's "The effect of automobile safety regulation". J. Econ. Issues 1977, 11, 587-600. [CrossRef]

6. Robertson, L.S. Automobile safety regulations and death reductions in the United States. Am. J. Public Health 1981, 71, 818-822. [CrossRef]

7. Wilde, G.J.S. The theory of Risk Homeostasis: Implications for Safety and Health. Risk Anal. 1982, 2, $209-225$. [CrossRef]

8. Wilde, G.J.S. Target Risk, 1st ed.; PDE Publications: Toronto, ON, Canada, 1994.

9. Wilde, G.J.S. Target Risk 3: Risk Homeostasis in Everyday Life, 2nd ed.; PDE Publications: Toronto, ON, Canada, 2014.

10. Evans, L. Risk Homeostasis Theory and Traffic Accident Data. Risk Anal. 1986, 6, 81-94. [CrossRef] [PubMed]

11. O'Neill, B.; Williams, A. Risk homeostasis hypothesis: A rebuttal (OPINION • DISSENT). Inj. Prev. 1998, 4 , 92-93. [CrossRef] [PubMed]

12. Baldwin, D.M. Sweden Changes to Right-Hand Driving; Highway Research Record. Issue Number: 234. Accession \#: 01410179; National Academies of Science: Washington, DC, USA, 1968; pp. 29-36.

13. Wilde, G.J.S. Remedy by engineering? The Munich taxicab experiment. In (In the pdf of Target Risk 3)—Risk Homeostasis in Everyday Life, 2nd ed.; PDE Publications: Toronto, ON, Canada, 2014; pp. 93-96.

14. Rader, R. Institute Calls on Government to Mandate Antilock Brakes for All New Motorcycles. Available online: http://www.iihs.org/iihs/news/desktopnews/institute-calls-on-government-to-mandate-antilockbrakes-for-all-new-motorcycles (accessed on 29 February 2016).

15. Anti-Lock Braking System Wikipedia. Available online: en.wikipedia.org (accessed on 29 February 2016).

16. Wilde, G.J.S.; Robertson, L.; Pless, I.B. For and Against: Does risk homoeostasis theory have implications for road safety? Br. Med. J. 2002, 324, 1149-1152. [CrossRef]

17. Peck, R.C. Do driver training programs reduce crashes and traffic violations?-A critical examination of the literature. IATSS Res. 2011, 34, 63-71. [CrossRef]

18. Mayhew, D.; Simpson, H. The Safety Value of Driver Education and Training. Inj. Prev 2002, 8, 3-8.

19. Robertson, L.S. Automobile safety regulation: Rebuttal and new data. Am. J. Public Health 1984, 74, 1390-1394. [CrossRef] [PubMed]

20. Morrongiello, B.A.; Major, K. Influence of safety gear on parental perceptions of injury risk and tolerance or children's risk taking. Inj. Prev. 2002, 8, 27-31. [CrossRef] [PubMed]

21. Morrongiello, B.A.; Walpole, B.; Lasenby, J. Understanding children's injury-risk behavior: Wearing safety gear can lead to increased risk taking. Accid. Anal. Prev. 2007, 39, 618-623. [CrossRef] [PubMed]

22. Lasenby-Lessard, J.; Morrongiello, B.A. Understanding risk compensation in children: Experience with the activity and level of sensation seeking play a role. Accid. Anal. Prev. 2011, 43, 1341-1347. [CrossRef] [PubMed]

23. DiLillo, D.; Tremblay, G. Maternal and child reports of behavioral compensation in response to safety equipment usage. J. Pediatr. Psychol. 2001, 26, 175-184. [CrossRef] [PubMed]

24. Pless, I.B.; Magdalinos, H.; Hagel, B. Risk-compensation behavior in children: Myth or reality? Arch. Pediatr. Adolesc. Med. 2006, 160, 610-614. [CrossRef] [PubMed] 
25. Consumer Product Safety Commission. Saving Lives through Legulatory Lonsensus: Child Lesistant Lackaging. Available online: http://www.cpsc.gov/scscpub/pubs/successppa.html (accessed on 5 May 1996).

26. Lawson, G.R.; Craft, A.W.; Jackson, R.H. Changing pattern of poisoning in children in Newcastle, $1974-81$. Br. Med. J. 1983, 287, 15-17. [CrossRef]

27. Rodgers, G.B. The safety effects of child-resistant packaging for oral prescription drugs: Two decades of experience. JAMA 1996, 275, 1661-1665. [CrossRef] [PubMed]

28. Walton, W.W. An evaluation of the Poison Prevention Packaging Act. Pediatrics 1982, 69, 363-370. [PubMed]

29. Smith, L.E.; Greene, M.A.; Singh, H.A. Study of the effectiveness of the US safety standard for child resistant cigarette lighters. Inj. Prev. 2002, 8, 192-196. [CrossRef] [PubMed]

30. Gamble, T.; Walker, I. Wearing a bicycle helmet can increase risk taking and sensation seeking in adults. Psychol. Sci. 2016, 27, 289-294. [CrossRef] [PubMed]

31. The New Daily. Available online: http://thenewdaily.com.au/life/tech/2015/11/22/riding-withouthelmet-should-be-legal/ (accessed on 15 September 2016).

32. Lee, J.M. Offsetting or Enhancing Behavior: An Empirical Analysis of Motorcycle Helmet Safety Legislation. Risk Anal. 2015, 35, 1820-1836. [CrossRef] [PubMed]

33. McNally, D.S.; Rosenberg, N.M. MADYMO simulation of children in cycle accidents: A novel approach in risk assessment. Accid. Anal. Prev. 2013, 59, 469-478. [CrossRef] [PubMed]

34. Fyhri, A.; Phillips, R.O. Emotional reactions to cycle helmet use. Accid. Anal. Prev. 2013, 50, 59-63. [CrossRef] [PubMed]

35. Messiah, A.; Constant, A.; Contrand, B.; Felonneau, M.L.; Lagarde, E. Risk compensation: A male phenomenon? Results from a controlled intervention trial promoting helmet use among cyclists. Am. J. Public Health 2012, 102 (Suppl. S2), S204-S206. [CrossRef]

36. Thomson, C.J.; Carlson, S.R. Increased patterns of risky behaviours among helmet wearers in skiing and snowboarding. Accid. Anal. Prev. 2015, 75, 179-183. [CrossRef] [PubMed]

37. Ruedl, G.; Abart, M.; Ledochowski, L.; Burtscher, M.; Kopp, M. Self reported risk taking and risk compensation in skiers and snowboarders are associated with sensation seeking. Accid. Anal. Prev. 2012, 48, 292-296. [CrossRef] [PubMed]

38. Rued, G.; Kopp, M.; Rump old, G.; Holster, B.; Ledochowski, L.; Burtscher, M. Attitudes regarding ski helmet use among helmet wearers and non-wearers. Inj. Prev. 2012, 18, 182-186. [CrossRef] [PubMed]

39. Ruedl, G.; Burtscher, M.; Wolf, M.; Ledochowski, L.; Bauer, R.; Benedetto, K.P.; Kopp, M. Are self-reported risk-taking behavior and helmet use associated with injury causes among skiers and snowboarders? Scand. J. Med. Sci. Sports 2015, 25, 125-130. [CrossRef] [PubMed]

40. Scott, M.D.; Buller, D.B.; Andersen, P.A.; Walkosz, B.J.; Voeks, J.H.; Dignan, M.B.; Cutte, G.R. Testing the risk compensation hypothesis for safety helmets in alpine skiing and snowboarding. Inj. Prev. 2007, 13, 173-177. [CrossRef] [PubMed]

41. Hagel, B.; Pless, I.B.; Goulet, C.; Platt, R.; Robitaille, Y. The effect of helmet use on injury severity and crash circumstances in skiers and snowboarders. Accid. Anal. Prev. 2005, 37, 103-108. [CrossRef] [PubMed]

42. Russell, K.; Christie, J.; Hagel, B.E. The effect of helmets on the risk of head and neck injuries among skiers and snowboarders: A meta-analysis. Can. Med. Assoc. J. 2010, 182, 333-340. [CrossRef] [PubMed]

43. Haider, A.H.; Saleem, T.; Bilaniuk, J.W.; Barraco, R.D. An evidence-based review: Efficacy of safety helmets in the reduction of head injuries in recreational skiers and snowboarders. J. Trauma Acute Care Surg. 2012, 73, 1340-1347. [CrossRef] [PubMed]

44. Ruedl, G.; Kopp, M.; Burtscher, M. Does Risk Compensation Undo the Protection of Ski Helmet Use? Epidemiology 2012, 23, 936-937. [CrossRef] [PubMed]

45. Wilde, G.J.S. Risk homeostasis theory: An overview. Inj. Prev. 1998, 4, 89-91. [CrossRef] [PubMed]

46. Haight, F.A. Risk, especially risk of a traffic accident. Accid. Anal. Prev. 1986, 18, 359-366. [CrossRef]

47. Evans, L. Traffic Safety and the Driver; Van Nostrand Reinhold: New York, NY, USA, 1991.

48. Rivara, F.P.; Johansen, J.M.; Thompson, D.C. Topics for systematic review. Inj. Prev. 2002, 8, 161-164. [CrossRef] [PubMed]

(C) 2016 by the author; licensee MDPI, Basel, Switzerland. This article is an open access article distributed under the terms and conditions of the Creative Commons Attribution (CC-BY) license (http://creativecommons.org/licenses/by/4.0/). 